\title{
Buckwheat (Fagopyrum esculentum Moench) characterization as adjunct in beer brewing
}

\author{
Viviane Cristina Buge BRASIL ${ }^{1}$, Bernardo Pontes GUIMARÃES ${ }^{1}$, Rafael Benjamin Werneburg EVARISTO${ }^{1}$, \\ Talita Souza CARMO², Grace Ferreira GHESTI ${ }^{1 *}$ (D)
}

\begin{abstract}
Given the scenario of buckwheat cultivation in Brazil, the research was developed evaluating its insertion in beer production as adjunct. The samples of interest were made with $55 \%(\mathrm{w} / \mathrm{w})$ barley malt and $45 \%(\mathrm{w} / \mathrm{w})$ buckwheat malt (45BWM), referenced to $100 \%$ Pilsen malt beer (AM). The results showed that the buckwheat malt wort had a $96.27 \%$ dry base extract, equivalent to the standard result. It also showed that glucose content increased 3 times, while the maltose and maltotriose have balances proportional. The use of buckwheat malt raised the protein content in more than $89 \%$, which is not seen from the use of other adjuncts and showed greater colloidal stability during the storage period, a factor associated with a 4-fold reduction of gluten content. Similar aspects regarding foam and turbidity pattern, although subtle differences in aromatic profile and flavors were present. Nevertheless, these factors show that is possible to use buckwheat as an adjunct in a Pilsen beer. The remaining sugars content gave a perspective on the metabolism of yeast during fermentation and the identification of some compounds by HPLC-MS was also able to demonstrate how buckwheat malt affected yeast metabolism due to wort composition.
\end{abstract}

Keywords: beer adjunct; gluten-free assistant; buckwheat.

Practical Application: Buckwheat as adjunct to Brazilian brewing process to produce Pilsen beer.

\section{Introduction}

The buckwheat (Fagopyrum esculentum Moench) has a short cycle (30 to 90 days of growth) and annual crop. It has cereal-like characteristics, such as barley or wheat but as it does not belong to the group of grasses, it is called a pseudocereal (Christa \& Soral-Smietana, 2008; Gao et al., 2016). It is used today in Brazil for animal and human food, soil cover and crop rotation. It is a low-cost crop, because it grows fast and have few pests; which makes its cultivation viable, but it practically not consumed in Brazil, which affects the market, especially in the Midwestern region of Brazil.

Buckwheat is commonly used in the food industry as flour for breads, pancakes and several other types of gluten-free foods. It is use as a source of proteins to coeliac products, since this grain has high protein value with no gluten in its composition; buckwheat husks can be used as landscaping fertilizer and can also be sold for packaging, cushions and mattresses (Boland, 2013).

Therefore, the inclusion of this pseudocereal in alcoholic beverages has been gaining strength in Brazil and internationally; the main objective of these productions is to benefit coeliac consumers, which comprise about $1 \%$ of the world population (Van Landschoot, 2011). Actually, it is one of the most cited grains in research for the manufacture of gluten-free malts and beers, since it has shown over the years, great results in terms of productivity, enzymatic ratio and chemical composition for the manufacture of fermented beverages (Buiatti et al., 2018; Wijngaard \& Arendt, 2006; Van Landschoot, 2011).
However, the insertion of any input of components in beer other than the traditional ones -barley malt, water, hops and yeast - directly impacts the final product. The use of adjunct affects both sensorial (mouthfeel, aromas and flavors) and physicochemical (foam, fermentation profile) characteristics of beer (Muller et al., 2019). It occurs due to changes in the composition of the wort which can induce reactions such as esterification and excessive deamination, among others during fermentation.

Brazil has its own legislation that directs the production of beer and determines the raw materials that can be used for its production. Decree No. 6871, of June 4, 2009, and the document titled Mercosur Technical Regulation for Beer Products, from Brazilian Ministry of Agriculture, Livestock and Supply (MAPA), informs the primary raw materials to produce the beverage called beer are barley malt, hops, and yeast (Muller, 2018). Barley malt can be replaced by brewers' adjuncts up to $45 \%$ in relation to the primitive extract of beer. The percentage of use of malting units differs greatly from one country or region to another. A study showed that Europe, for example, used only about 10 to $30 \%(\mathrm{~m} / \mathrm{m})$ of assemblers in a brewing operation, while in the United States it is common to exchange 40 to $60 \%(\mathrm{~m} / \mathrm{m})$ in a common recipe. The countries that change the composition of beer in greater quantities would be those in Africa that tend to replace barley malt in up to $75 \%$ of the recipe with sorghum as the primary source of enzymes (Muller, 2018).

${ }^{1}$ Laboratório de Bioprocessos Cervejeiros e Catálise em Energias Renováveis (LaBCCERva), Instituto de Química, Universidade de Brasília - UnB, Brasília, DF, Brasil ${ }^{2}$ Grupo Engenharia de Biocatalisadores, Departamento de Biologia Celular, Instituto de Ciências Biológicas, Universidade de Brasília - UnB, Brasília, DF, Brasil

*Corresponding author: ghesti.grace@gmail.com 
Surveys conducted between 2010 and 2012 reported the use of adjuncts brewers in the proportion of $95.6 \%$ in large breweries, with $91.3 \%$ of the Pilsen-type beers surveyed used as adjuncts derived from corn or cane sugar. It is known that the current scenario is not very different for large breweries, so there is the possibility of using buckwheat if the survey shows satisfactory results after scaling up. Literature shows that the commonly used adjuncts impacts final presentation, damaging the body and foam of the product due to its low protein content (D’Avila et al., 2012).

That way using adjuncts affect composition and physicochemical properties in some way. Phiarais et al. (2010) recommended at least $100 \mathrm{mg} / \mathrm{L}$ of nitrogen content to be adequate for the brewing process. For a 100\% buckwheat malt beer the content found was $164 \mathrm{mg} / \mathrm{L}$, which was higher than the minimum required, representing a healthy amount for yeast growth. Buiatti et al. (2018) observed that the substitution of barley malt to gluten-free beer promoted a greater colloidal stability during storage. This indicates an increase in hot break formation, thus a cleaner beer as most protein and bigger peptides are removed from beer by precipitation. Polyphenols are also of great importance and can promote substantial differences to the final product. Rutin, for example, can vary from 126 to $366 \mathrm{mg} / \mathrm{g}$ of the grain, with the highest values being observed in the grain during the germination period.

As with barley grains, carbohydrates make up the bulk of buckwheat. The carbohydrate content is between 59 and 70\% of its mass. The availability of starch in the grain is also high, 70 to $91 \%$, and may vary according to the amount of protein in the crop; $33 \%(\mathrm{~m} / \mathrm{m})$ of starch refers to resistant starch (Ahmed et al., 2014; Kreft et al., 2006).

Based on the fall in international trade of this pseudocereal, it is important to solve the hyper-supply by diversifying the use of this input, which has great value if considering its nutritional parameters and possible exploitation of other characteristics in the scientific environment. Thus, this study was conducted to indicate viable technological paths for its use, specifying the subject of this study to be used in the increase of the functionalities of beer.

Considering the buckwheat nutritional characteristics and market availability, the objective of this work was to study the insertion of buckwheat as an adjunct in the brewing process. Evaluating its impacts on the production process along with the physicochemical and organoleptic characteristics of beer. It is known that buckwheat cultivation in the Midwestern region of Brazil is extensive and has low marketing costs.

\section{Materials and methods}

\subsection{Buckwheat and Buckwheat malt}

Agrícola Sempre Viva (Distrito Federal, Brazil) and Maltes Catarinense (Santa Catarina, Brazil), respectively, gave the buckwheat in natura and buckwheat malt used in this work. Pilsen malt was purchased from Maltaria Agrária (Santa Catarina, Brazil). Moisture content was determined by EBC 6.1. Extract of malt was measured in Congress mash as stated in EBC 4.5.1 and extract of wort was measured according to EBC 8.3. The samples labels are buckwheat in natura (BW), malted buckwheat (BWM),
$45 \%(\mathrm{~m} / \mathrm{m})$ of buckwheat $(45 \mathrm{BW}), 45 \%(\mathrm{~m} / \mathrm{m})$ buckwheat malt (45BWM) and 55\% (m/m) Pilsen malt, and 100\% Pilsen malt (AM).

\subsection{Mash and beer analyses}

Sample beers were brewed with $45 \%(\mathrm{~m} / \mathrm{m})$ of buckwheat malt $(45 \mathrm{BW})$ and $55 \%(\mathrm{~m} / \mathrm{m})$ Pilsen malt and a reference beer was prepared with $100 \%$ Pilsen malt (AM). They were fermented at $12{ }^{\circ} \mathrm{C}$ using the lager yeast SafBrew Lager DCL/Fermentis S33 - 1,500,000 cells $/ \mathrm{mL}^{\circ}$ Plato (Fermentis, France) for $168 \mathrm{~h}$ and maturated at $0^{\circ} \mathrm{C}$ for other $168 \mathrm{~h}$. Extract content of solid adjuncts was measured as in EBC 6.3. Wort and beer viscosity were measured according to $\mathrm{EBC} 9.13 ; \mathrm{pH}$ and density were measured according to EBC 8.17 and EBC 8.2.2, respectively. Total polyphenols in beer was determined by EBC 9.11 and UV spectrometer SpectraMax M2 (Molecular Devices, United States) at $600 \mathrm{~nm}$.

Soluble protein content was quantified by Bradford method (Sigma Aldrich, United States) via UV spectroscopy at $595 \mathrm{~nm}$ of SpectraMax M2 (Molecular Devices, United States). Beer physicochemical characteristics such as alcohol content, fermentability were measured with PBA-B M-AltonPaar equipped with AlcolyzerPlus Beer and density detector DMA $5000 \mathrm{M}$ (AntonPaar, Austria). Gluten content was quantified via ELISA.

Fermentable carbohydrates and organic acids were measured by EBC 8.7 with an HPLC Shimadzu Shim-Pack SCR 101-H $(300 \times 7.9 \mathrm{~mm})$ and UV detector SPD-20A for organic acids and refraction index detector RID-10A for carbohydrates and alcohols (Shimadzu Corporation, 2017; Guilherme et al., 2015). The fermentation byproducts were analyzed using a high performance liquid chromatography equipment (HPLC; Shimadzu, Kyoto, Japan) equipped with a mass spectrometry detector. The analytical parameters of the chromatographic analyses were determined qualitatively with $95 \%$ precision.

Sensorial analysis results were divided into aromas and flavor for each sample. The file had a 1-5 grading system, where 1 was the least and 5 the highest sensorial perception. The average perception for each characteristic was calculated and expressed as a spider graph for visual representation.

\section{Results and discussion}

Moisture content of buckwheat, malted buckwheat and Pilsen malt are under $12 \%$, which means no further drying treatment is required for proper use or storage (Esslinger, 2015; Mazza \& Oomah, 2003). Pilsen malt obtained the lowest moisture content (4.68 $\pm 0.12 \%)$; buckwheat grains, $11.07 \pm 0.04 \%$ and buckwheat malt, $10.73 \pm 0.20 \%$.

\subsection{Congress mash}

In previous studies, the best relation of Pilsen malt to buckwheat was 0.55:0.45 to optimize yield and extract (Brasil, 2019). Physicochemical properties of the congress mash with $100 \%$ buckwheat (100BW), 100\% buckwheat malt (BWM), $45 \%$ buckwheat (45BW), 45\% buckwheat malt (45BWM) and 100\% Pilsen malt (AM) are shown in Table 1. 
The mash of 100BW, 100BWM and 45BWM did not have a significant difference mash $\mathrm{pH}$ when compared to the reference mash, $\operatorname{AM}(4.93, \mathrm{p}=0.05)$, which is crucial to the brewing process since the grains are responsible for $\mathrm{pH}$ buffering for enzymatic activity and protein coagulation. $45 \mathrm{BW}$ showed a slight increase in its $\mathrm{pH}, 5.06$. Ideally mash pH should be 5.1 - 5.3 (Bamforth, 2017); but as the solubility of buckwheat proteins is lowest between pH 4 and 5 (Tomotake et al., 2002), this is the ideal pH range for buckwheat hot break and trub formation, as it contributes more than barley to mash protein (as seen in Table 1 for protein content). The mash $\mathrm{pH}$ for all samples are up to 0.2 outside the ideal mash $\mathrm{pH}$, which means none or little interference in enzyme activity was observed, besides, the buckwheat mash samples did not require the use of acid or salt to correct the $\mathrm{pH}$ in order to guarantee colloidal stability (Tomotake et al., 2002).

Considering the specific gravity, the addition of buckwheat reduced the density in 100BW, 100BWM and 45BW to 1.034 , while 45BWM and AM obtained the same value (1.040, $\mathrm{p}=0.05)$. In relation to the original extract measured by degrees Plato, 100BW, 100BWM and 45BW had lower values as expected for adjuncts addition (Buiatti et al., 2018), $8.46^{\circ} \mathrm{P}, 8.78^{\circ} \mathrm{P}$ and $8.21^{\circ} \mathrm{P}$, respectively. Interestingly $45 \mathrm{BWM}$ showed no significant difference compared to AM $(10.23, \mathrm{p}=0.05)$, probably due to enzymatic concentration promoted by barley malt associated to the enzymatic content from buckwheat malt.

Regarding the properties of the mash, 45BWM and AM obtained similar extract content $(91.59 \%)$ and dry matter basis (96.02\%), while the other samples obtained lower values like 100BWM, $76.90 \%$ for extract and 82.66 for dry matter. Pilsen barley malt has higher concentration of $\alpha$ - and $\beta$-amylases than buckwheat in natura or malt, having more than enough to breakdown the adjunct starch along with its own (Wijngaard et al., 2005; Phiarais et al., 2010; Wijngaard et al., 2007). That way higher extraction content was observed for 45BWM in comparison with $45 \mathrm{BW}$ since the enzymes present in malt buckwheat associated with the ones presented in barley malt resulting in more efficient hydrolysis. This type of comparison can be clearly seen in the extract content of 100BW and 100BWM where malting process made significant distinction.

In all samples with buckwheat the protein content (349 to $358 \mathrm{mg} / \mathrm{L}$ ) was roughly twice that of $100 \%$ barley malt $(184 \mathrm{mg} / \mathrm{L})$. Buckwheat is known for having a nitrogen-rich composition (Buiatti et al., 2018). It was observed that the reduction in the buckwheat amount from $100 \%$ to $45 \%$ did not change significantly the protein content, which suggests more trub formation. In spite of the data presented in Table 1, studies with other adjuncts report that adding adjuncts negatively impacts nitrogen content, especially FAN and foam stability as most of the cereals used have little protein content (MacLeod \& Evans, 2015).

The viscosity increased with the addition of buckwheat. 45BW and 45BWM used less buckwheat and consequently less viscosity was observed (1.72 and $1.79 \mathrm{mPa} . \mathrm{s}^{-1}$, respectively) than 100BWM or 100BW (1.99), all of them were still higher than AM $(1.34, \mathrm{p}=0.05)$; which can be associated by the higher protein content and starch resistant to degradation or other soluble carbohydrates (Pires \& Brányik, 2015).

Considering the data here reported, the mash with $45 \%$ buckwheat malt was the most suitable to proceed to fermentation as it is the closest to the reference mash, obtaining only higher protein content and viscosity.

\subsection{Beer}

During fermentation, the specific gravity (associated to extract content) and $\mathrm{pH}$ drop as yeast multiplied and consumed the dissolved sugars while secreting alcohol, $\mathrm{CO}_{2}$, and fermentation by-products. Figure 1 shows the profile of these variables during fermentation. After $120 \mathrm{~h} 45 \mathrm{BWM}$ and AM had a pH of $5.14 \pm 0.03$ and $4.61 \pm 0.09$, respectively. It was observed that $45 \mathrm{BWM}$ had a $\mathrm{pH}$ increase after $96 \mathrm{~h}$ when it peaked its minimum, $4.81 \pm 0.07$, indicating aminoacid oxidation (European Brewery Convention, 2007; Parachin \& Ghesti, 2017).

The specific gravity of 45BWM stabilized after $48 \mathrm{~h}$ of fermentation, whereas AM was only after $72 \mathrm{~h}$. This means that they ended fermentation at different times, which might be due to different fermentable sugar concentration in their composition and consequently absorption rate by yeast (White, 2010; European Brewery Convention, 2007). As did with pH, after $96 \mathrm{~h}$ 45BWM showed an increase in its specific gravity.

In order to better understand the role of buckwheat malt as adjunct, some of the dissolved carbohydrates were quantified by HPLC, namely: glucose, maltose and maltotriose; along with the major fermentation product, alcohol.

The carbohydrate content in both beer samples were analyzed before fermentation process, as seen in Table 2. 45BWM had a

Table 1. Physicochemical properties of congress mash with 100\% buckwheat (100BW), 100\% buckwheat malt (100BWM), 45\% buckwheat (45BW), 45\% buckwheat malt (45BWM) and 100\% Pilsen malt (AM).

\begin{tabular}{lccccc}
\hline \multicolumn{1}{c}{ Analysis } & $100 \mathrm{BW}$ & $100 \mathrm{BWM}$ & $45 \mathrm{BW}$ & $45 \mathrm{BWM}$ & AM \\
\hline $\mathrm{pH}$ & $4.99 \pm 0.06$ & $4.90 \pm 0.03$ & $5.06 \pm 0.05$ & 4.900 .03 & $4.93 \pm 0.03$ \\
Specific gravity $(\mathrm{g} / \mathrm{mL})$ & $1.034 \pm 0.002$ & $1.035 \pm 0.001$ & $1.033 \pm 0.002$ & $1.040 \pm 0.001$ & $1.041 \pm 0.001$ \\
Original Extract $(\mathrm{o})$ & $8.46 \pm 0.37$ & $8.78 \pm 0.28$ & $8.21 \pm 0.00$ & $9.99 \pm 0.00$ & $10.23 \pm 0.00$ \\
Extract (\%) & $70.73 \pm 3.58$ & $76.90 \pm 2.70$ & $75.44 \pm 0.00$ & $89.56 \pm 0.00$ & $91.59 \pm 2.79$ \\
Dry matter extract (\%) & $76.85 \pm 3.90$ & $82.66 \pm 2.98$ & $81.97 \pm 0.00$ & $96.27 \pm 0.00$ & $96.09 \pm 2.92$ \\
Protein (mg/L) & $358 \pm 4$ & $359 \pm 1$ & $350 \pm 4$ & $349 \pm 2$ & $184 \pm 3$ \\
Viscosity $\left(\mathrm{mPas}^{-1}\right)$ & $1.99 \pm 0.00$ & $1.92 \pm 0.06$ & $1.72 \pm 0.08$ & $1.79 \pm 0.00$ & $1.34 \pm 0.01$ \\
\hline
\end{tabular}




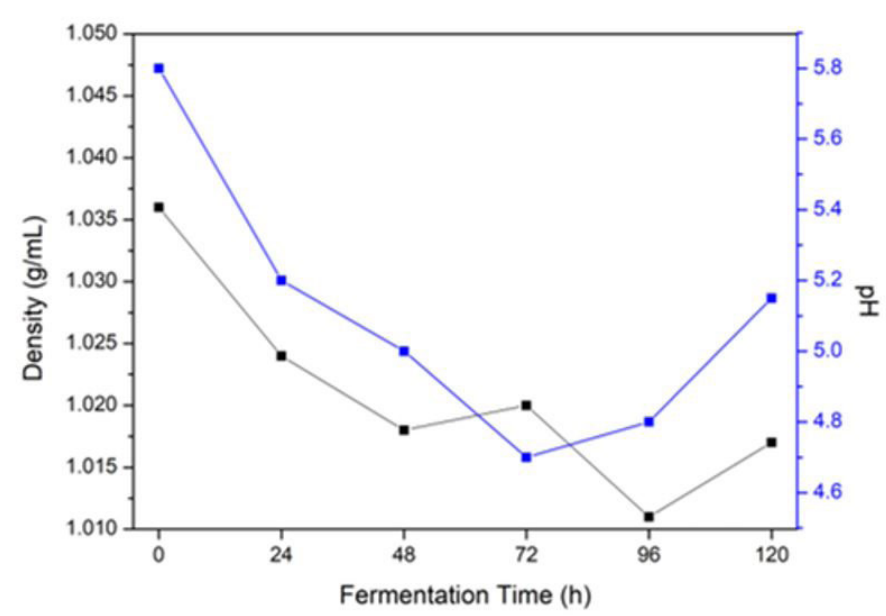

(A)

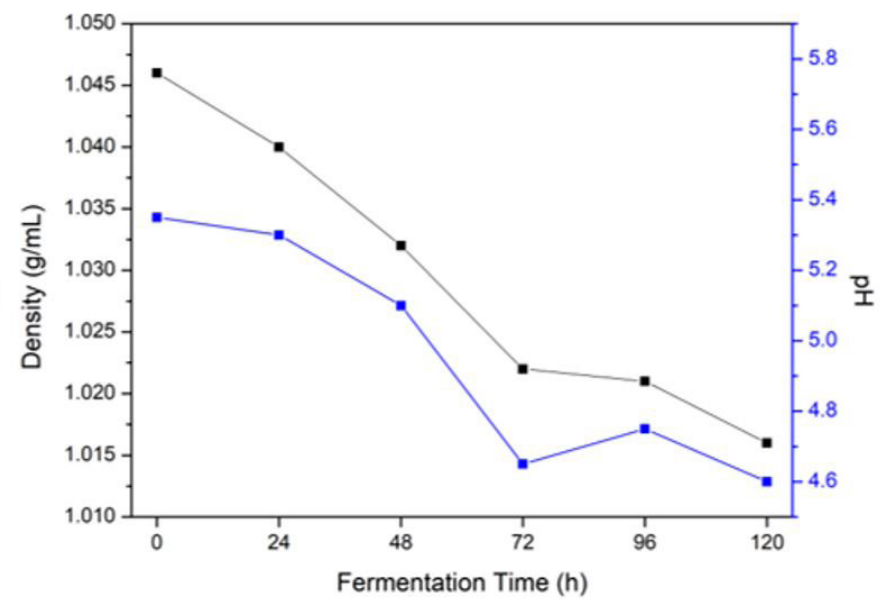

(B)

Figure 1. Specific gravity (black) and $\mathrm{pH}$ (blue) of 45BWM (A) and AM (B) during fermentation.

sugar profile much different than that of AM, with glucose being the most abundant carbohydrate $(23.75 \mathrm{~g} / \mathrm{L})$, followed by maltose $(15.31 \mathrm{~g} / \mathrm{L})$ and maltotriose $(6.33 \mathrm{~g} / \mathrm{L})$; while AM had $32.11 \mathrm{~g} / \mathrm{L}$ of maltose, $10.26 \mathrm{~g} / \mathrm{L}$ of glucose and $8.83 \mathrm{~g} / \mathrm{L}$ of maltotriose. This difference in sugar concentration, which roughly 3 times more glucose than AM, has been reported by Phiarais et al. (2010) and Wijngaard et al. (2007). Our finding was lower than the first who used exogenous enzymes to saccharify buckwheat and obtained $28.6 \mathrm{~g} / \mathrm{L}$ of glucose and the latter who obtained $54.53 \mathrm{~g} / \mathrm{L}$ after malt optimizing. This means that employing exogenous enzymes could improve mash yield and consequently higher alcohol content and fermentation degree.

Differences in maltose and maltotriose content in 45BWM wort in comparison to AM ( $52 \%$ and $38.30 \%$ content reduction, respectively) suggest that these carbohydrates come mostly from barley (since there was a part of barley malt that was substituted and the decrease followed the percentage of BWM added). The overall amount of mols of carbon in $45 \mathrm{BWM}$ is $89.7 \%$ that of AM, which means a reduction in available carbon for fermentation of roughly $10 \%$, consequently, beer from 45BWM is expected to be slightly less alcoholic and with a lower degree of fermentation (Briggs, 1998; Mallett, 2014).

Due to the high concentration of monosaccharide in 45BWM original wort (before fermentation), its fermentation profile was not the same as usually reported for lager yeast. As can be seen in fermentation profile presented in Figure 2, it was observed a high glucose consumption since the beginning until stabilization in $72 \mathrm{~h}$ while also maltose and maltotriose was consumed since the beginning at a steady rate until its constancy in $72 \mathrm{~h}$. AM on the other hand showed a typical fermentation profile for lager, with a high glucose consumption in the first $24 \mathrm{~h}$, followed by a decrease in its consumption and prioritizing maltose instead. At the end of the fermentation period (120 h), 45BWM decreased its maltose concentration in $88.86 \%$ and AM in $97.06 \%$.

During fermentation some organic acids and glycerol may be produced and secreted to beer by yeast, Figure 3 shows their profile formation. In both cases, acetic and lactic acid was close to zero during the entire process, meaning no significant contamination
Table 2. Sugar concentration $(\mathrm{g} / \mathrm{L})$ in $45 \%$ buckwheat malt (45BWM) and $100 \%$ Pilsen malt (AM) beer before fermentation.

\begin{tabular}{lcccc}
\hline Sample & $\begin{array}{c}\text { Glucose } \\
(\mathrm{g} / \mathrm{L})\end{array}$ & $\begin{array}{c}\text { Maltose } \\
(\mathrm{g} / \mathrm{L})\end{array}$ & $\begin{array}{c}\text { Maltotriose } \\
(\mathrm{g} / \mathrm{L})\end{array}$ & Total $(\mathrm{g} / \mathrm{L})$ \\
\hline $45 \mathrm{BWM}$ & 23.75 & 15.31 & 6.33 & 45.39 \\
$\mathrm{AM}$ & 8.83 & 32.11 & 10.26 & 51.20 \\
\hline
\end{tabular}

occurred. Citric acid and succinic acid are intermediates in the Krebs cycle being produced during yeast growth but can also be produced by amino acid oxidation. Citric acid was very low (under $0.25 \mathrm{mg} / \mathrm{mL}$ ) during the time period for both samples.

45BWM had a bumpy steady increase in succinic acid during the whole fermentation time, while AM had a significant production in the first $24 \mathrm{~h}$ increasing to its maximum in $72 \mathrm{~h}$ but stabilizing with a small decrease after 96h. Succinic acid is produced via oxidative pathway in aerobic conditions, explaining its production in the first $24 \mathrm{~h}$. In anaerobic conditions, succinate may me produced via a reductive pathway for an aplerosis (Raab et al., 2010; Kallscheuer, 2018). Both samples had an increasing, constant and steady glycerol production throughout the time period analyzed.

The analysis of final beer samples and their physicochemical parameters are displayed in Table 3. It is important to highlight that those analyses were conducted after maturation process (final product evaluation). Despite having similar mash properties, final beer differed significantly in all physicochemical parameters analyzed. 45BWM obtained a higher specific gravity, which is expected as it had a higher protein and polyphenol content, consequently its real degree of fermentation (RDF) and alcohol production were lower than $\mathrm{AM}(\mathrm{p}=0.05)$. The remaining sugar content shown in Figure 2 was confirmed in this analysis in which $45 \mathrm{BWM}$ had $3.59 \mathrm{~g} / \mathrm{L}$ against $1.30 \mathrm{~g} / \mathrm{L}$ in AM. As stated above, the use of amylases to further degrade buckwheat starch and dextrins could improve RDF, alcohol content and reduce remaining sugar content as more mono and disaccharides would be available to yeast. 


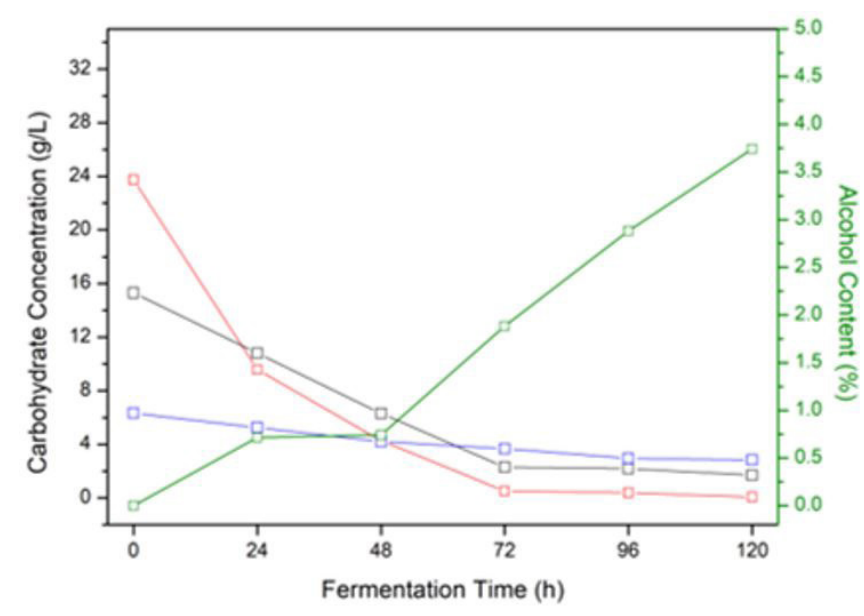

(A)

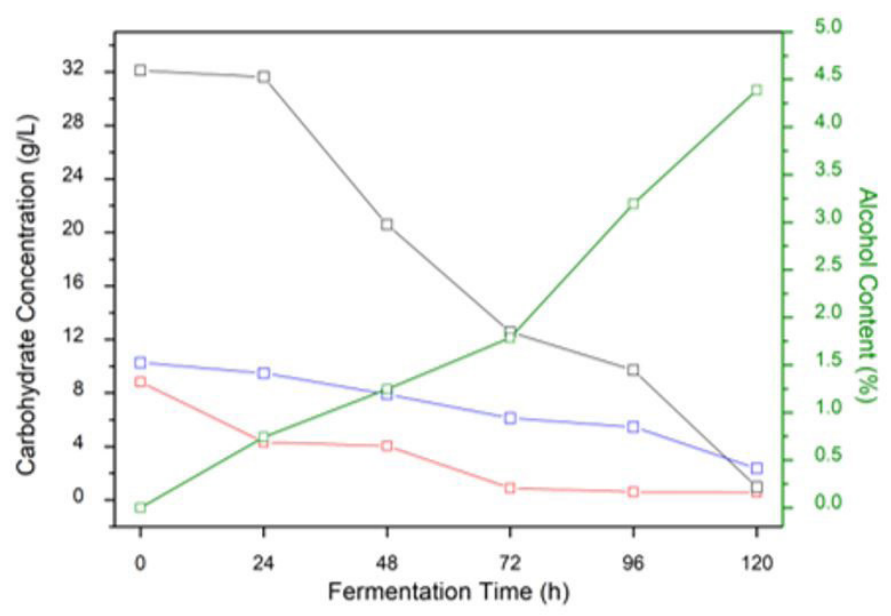

(B)

Figure 2. Fermentation profile of 45BWM (A) and AM (B). Glucose (red), maltose (black), maltotriose (blue) and ethanol (green).

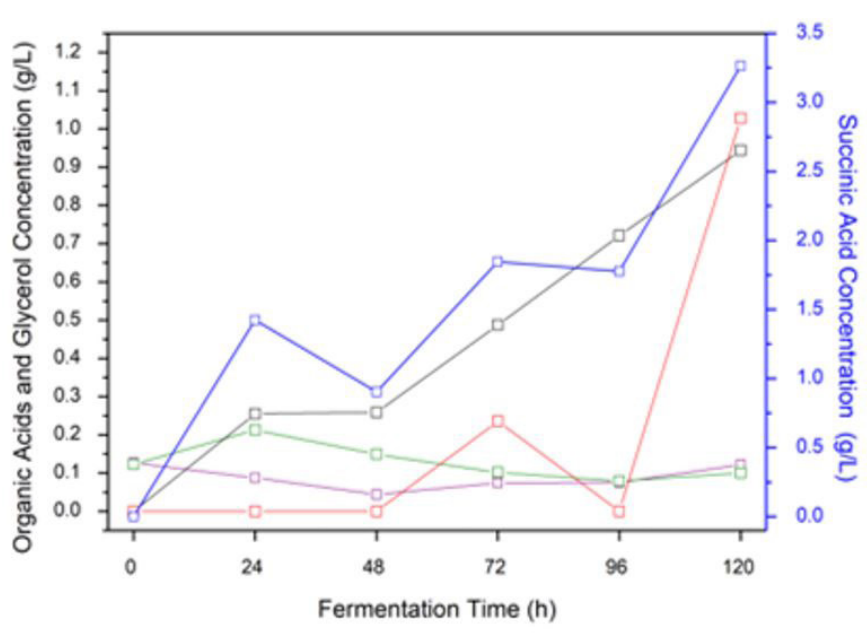

(A)

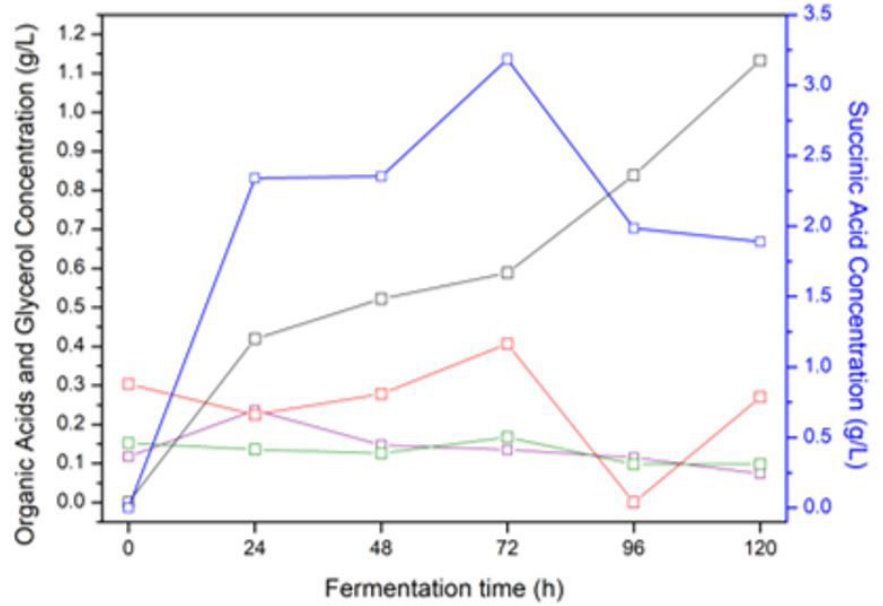

(B)

Figure 3. Organic acid and glycerol production during fermentation time for 45BWM (A) and AM (B). Succinic acid (blue), citric acid (green), acetic acid (purple), lactic acid (red) and glycerol (black).

Table 3. Physicochemical properties of $45 \%$ buckwheat malt (45BWM) and Pilsen malt (AM) beers.

\begin{tabular}{lcc}
\hline \multicolumn{1}{c}{ Parameter } & 45BWM & \multicolumn{1}{c}{ AM } \\
\hline Specific gravity $(\mathrm{g} / \mathrm{mL})$ & $1.012 \pm 0.000$ & $1.003 \pm 0.001$ \\
Real degree of Fermentation $(\%)$ & $54.84 \pm 0.23$ & $70.99 \pm 1.24$ \\
Alcohol $(\% \mathrm{v} / \mathrm{v})$ & $3.74 \pm 0.08$ & $4.39 \pm 0.07$ \\
Real extract $(\% \mathrm{~m} / \mathrm{m})$ & $4.96 \pm 0.07$ & $2.91 \pm 0.22$ \\
Calories $(\mathrm{kJ} / 100 \mathrm{~mL})$ & $160.94 \pm 3.03$ & $144.38 \pm 4.91$ \\
Remaining sugars $(\mathrm{g} / \mathrm{L})$ & $3.59 \pm 0.04$ & $1.30 \pm 0.20$ \\
Total polyphenol content $(\mathrm{mg} / \mathrm{L})$ & $329.41 \pm 21.33$ & $130.06 \pm 8.68$ \\
Gluten content $(\mathrm{mg} / \mathrm{L})$ & 0.07 & 0.31 \\
\hline
\end{tabular}

The total polyphenol content of 45BWM (329.41 mg/L) was much higher than AM (130.06 mg/L) and the gluten content was much lower $(0.07 \mathrm{mg} / \mathrm{L})$ than AM $(0.31 \mathrm{mg} / \mathrm{L})$. Such significant differences in polyphenol and gluten content between the samples shows that not only the fact that the substitution of barley malt for buckwheat malt had impacts, but also that the proportion of BWM added did not follow the decrease percentage in gluten content indicating that gluten has precipitated with proteins by the assistance of polyphenols (Kunze, 2004; Ahmed et al., 2014; Hager et al., 2014; Buiatti et al., 2018). As buckwheat beer had a higher polyphenolic content, it may present colloidal instability (haze) once beer ages, modifying its sensorial characteristics. To overcome this issue either polyvinylpolypyrrolidone (PVPP) or silica could be employed, reducing the polyphenolic or protein content, respectively. 
The overall physicochemical properties of 45BWM suggests a beer with sweet and phenolic aroma and taste, alcoholic taste less apparent and with greater body than 100\% barley malt reference beer.

\subsection{Sensorial analysis}

The sensorial panel did not find any strong aroma in either beer (Figure 4), with spicy and yeast being the most prominent ones both with 1.6 and higher than in Pilsen (1.2 and 1.3 respectively), on a 5 -grading system. Buckwheat malt beer had a spicier and more tannic aroma, probably due to its higher polyphenol concentration. The taste of buckwheat beer was also tannic, yet vanilla and flour were detected stronger than in AM. In addition to that, it was observed a longer head retention which is unusual for most beer adjuncts (Colgrave et al., 2012; Buiatti et al., 2018) along with no turbidity and a paler color as expected from them. Therefore, this adjunct does not interfere in Pilsen beer visual characteristics (Newman \& Newman, 2008).

\subsection{Chromatography analysis - byproducts compound formation}

HPLC-MS analysis identified acetates, aldehydes, lactones and superior alcohols in buckwheat beer (45BWM) which were not detected in the AM sample, as listed in Table 4. Most of them are produced by amino and organic acids catalysis.

Furfural and phenylethyl acetate were identified in both beers, although their concentration were 1.3 and 2.0 times higher in the one brewed with buckwheat. Their production is strictly related to the nitrogen catabolic pathway, suggesting no yeast stress as they are repressed in such conditions. These molecules have a fruity or floral aroma (Holt et al., 2019); however, they were not identified by the sensorial panel, which indicates lower concentration than perception threshold. This supports the evidence that buckwheat can be promptly used for brewing adding nutrients to yeast metabolism.

Aldehydes are commonly associated with fruity or sweet aromas (Holt et al., 2019; Muller et al., 2019). Amongst this class of compound, phenylacetaldehyde identified in buckwheat beer, it is an intermediate in 2-phenylethanol production by yeast which is also found in buckwheat beers (Wishart et al., 2018).

Table 4. Chemical compounds identified by HPLC-MS in 45BWM and $\mathrm{AM}$ beer.

\begin{tabular}{lcc}
\hline \multicolumn{1}{c}{ Chemical compound } & Aroma & Beer identified \\
\hline & Alcohols \\
\hline 2-methylbutan-1-ol & Solvent & AM, 45BWM \\
3-methylbutan-1-ol & Solvent & AM, 45BWM \\
2-phenylethan-1-ol & Roses, floral, honey & 45BWM \\
\hline \multicolumn{3}{c}{ Esters } \\
\hline 2-phenylethyl acetate & Floral, honey & 45BWM \\
Heptyl acetate & Fruity & AM, 45BWM \\
Furfural acetate & Floral, fruity & $45 \mathrm{BWM}$ \\
Phenylethyl acetate & Fruity & $45 \mathrm{BWM}$ \\
\hline \multicolumn{3}{c}{ Aldehyde } \\
\hline Phenylacetaldehyde & Floral, sweet & 45BWM \\
\hline \multicolumn{3}{c}{ Spicy-aroma related molecules } \\
\hline 5-methylfurfural & Spicy & AM, 45BWM \\
4-methoxybenzyl alcohol & Coconut & $45 \mathrm{BWM}$ \\
p-anisyl alcohol & Anis & $45 \mathrm{BWM}$ \\
\hline
\end{tabular}

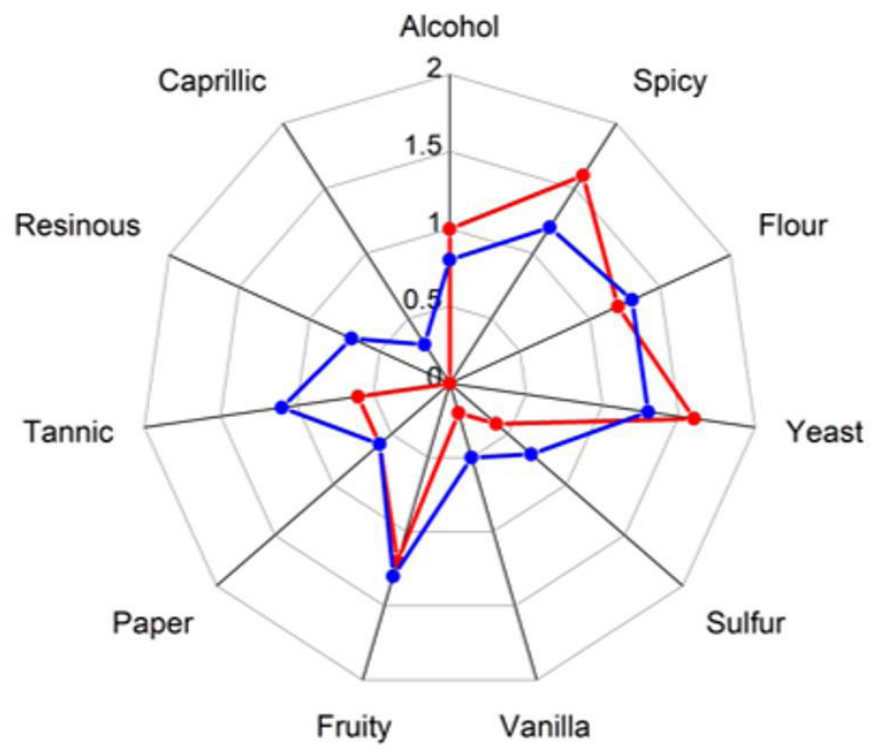

(A)

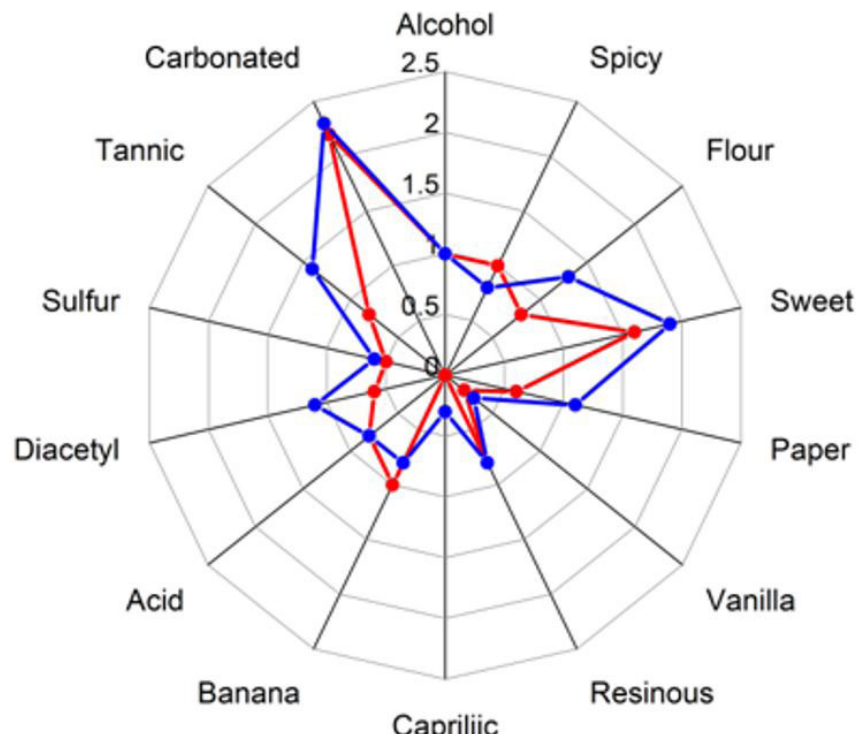

(B)

Figure 4. Aroma (A) and taste (B) profiles of 45BWM (red) and AM (blue). 
As HPLC-MS was not used as a quantitative analysis, it may be from either buckwheat malt or its association with yeast. Either way it favored the formation of superior alcohols (2-phenylethanol), and 2-phenylethyl acetate. 5-methylfurfural was also identified. Despite being an aldehyde, it has a spicy organoleptic characteristic (Guimarães et al., 2020). It is a common product of malt Maillard reaction (Guimarães et al., 2020).

$\gamma$-nonalactone originates from fatty acid oxidation followed by Maillard reactions and might come from the malting or even mashing by enzymatic reactions. It is a common compound found in whiskeys, commonly associated with a coconut aroma (Starowicz et al., 2018; Holt et al., 2019; An \& Oh, 2013). This means buckwheat could be employed to enrich wood-aged beer as they seek this spicier aroma and taste, even using old whiskey barrels (Guimarães et al., 2020).

$\mathrm{P}$-anisyl alcohol is a reduction product of $\mathrm{p}$-anisaldehyde, a compound originally from buckwheat (Starowicz et al., 2018). Its reduction is associated with the reductive medium caused by the high glycolysis rate, as it is favored by the presence of NADH.

\section{Conclusion}

Buckwheat can be used as beer adjunct with the advantage of having a high protein and polyphenol content. The use of its malt instead of the in natura grain in association with barley malt in a $45-55 \%(\mathrm{~m} / \mathrm{m})$ ratio is even more interesting as their mash is the closest to that of a $100 \%$ barley malt. Its use is recommended for beers with lower gluten content or with higher nutrition value. Yet, the use of exogenous enzymes would still be an interesting choice to improve starch degradation and alcohol content.

The different fermentation profile for buckwheat beer with a higher initial glucose concentration is crucial to alcohol and other fermentation products, altering positively its aroma and taste. Nevertheless, its high polyphenolic content may cause a weak astringent taste and turbidity as beer ages. Buckwheat beer had a spicy and sweet aroma with the presence of a coconut aroma, caused by 5 -methylfurfural. This compound is common in whiskeys; thus, buckwheat could be employed to whiskey and wood-aged beer as they seek a spicier aroma.

\section{Acknowledgements}

The authors appreciate the financial support of the National Council for Scientific and Technological Development (CNPq), the Coordination of Superior Level Staff Improvement (CAPES) and the Federal District Research Support Foundation (FAPDF), also would like to thank Agrária Sempre Viva and Maltes Catarinense for providing the buckwheat samples for this study, Drinks Counterfeiting Laboratory of the Federal District Civil Police (PC-DF) for the utilization of equipment for physicochemical beer analysis, Molecular Biology Laboratory from the University of Brasília (IB/UnB) and also the Institute of Chemistry (IQ/ $\mathrm{UnB}$ ) for providing laboratory installations for analysis and experimental data acquisition.

\section{References}

Ahmed, A., Khalid, N., Ahmad, A., Abbasi, N. A., Latif, M. S. Z., \& Randhawa, M. A. (2014). Phytochemicals and biofunctional properties of buckwheat: a review. The Journal of Agricultural Science, 152(3), 349-369. http://dx.doi.org/10.1017/S0021859613000166.

An, J. U., \& Oh, D. K. (2013). Increased production of $\gamma$-lactones from hydroxy fatty acids by whole Waltomyces lipofer cells induced with oleic acid. Applied Microbiology and Biotechnology, 97(18), 82658272. http://dx.doi.org/10.1007/s00253-013-5089-1. PMid:23868297.

Bamforth, C. W. (2017). Progress in brewing science and beer production. Annual Review of Chemical and Biomolecular Engineering, 8(1), 161176. http://dx.doi.org/10.1146/annurev-chembioeng-060816-101450. PMid:28301731.

Boland, M. (2013). Buckwheat profile. USA: Agricultural Marketing Resource Center. Retrieved from http://www.agmrc.org/commoditiesproducts/specialty-crops/buckwheat-profile/

Brasil, V. C. B. (2019). Caracterização e uso do trigo Sarraceno (Fagopyrum esculetum) como adjunto na produção de cerveja (Dissertação de mestrado). Universidade de Brasília, Brasília.

Briggs, D. E. (1998). Malts and malting. Birmingham: Blackie Academic \& Professional.

Buiatti, S., Bertoli, S., \& Passaghe, P. (2018). Influence of gluten-free adjuncts on beer colloidal stability. European Food Research and Technology, 244(5), 903-912. http://dx.doi.org/10.1007/s00217017-3010-3.

Christa, K., \& Soral-Śmietana, M. (2008). Buckwheat grains and buckwheat products - Nutritional and prophylactic value of their components - A review. Czech Journal of Food Sciences, 26(3), 153162. http://dx.doi.org/10.17221/1602-CJFS.

Colgrave, M. L., Goswami, H., Howitt, C. A., \& Tanner, G. J. (2012). What is in a beer? Proteomic characterization and relative quantification of hordein (gluten) in beer. Journal of Proteome Research, 11(1), 386-396. http://dx.doi.org/10.1021/pr2008434. PMid:21999962.

D’Avila, R. F., Luvielmo, M. M., Mendonça, C. R. B., \& Jantzen, M. M. (2012). Adjuntos utilizados para produção de cerveja: características e aplicações. Estudos Tecnológicos Em Engenharia, 8(2), 60-68. http:// dx.doi.org/10.4013/ete.2012.82.03.

Esslinger, H. M. (2015). Handbook of brewing (Vol. 1). Boca Raton: CRC Press.

European Brewery Convention - EBC. (2007). Fermentation \& maturation (manual of good practice) (Vol. 7). Nuremberg, Germany: Fachverlag Hans Carl.

Gao, J., Kreft, I., Chao, G., Wang, Y., Liu, X., Wang, L., Wang, P., Gao, X., \& Feng, B. (2016). Tartary buckwheat (Fagopyrum tataricum Gaertn) starch, a side product in functional food production, as a potential source of retrograded starch. Food Chemistry, 190, 552-558. http://dx.doi.org/10.1016/j.foodchem.2015.05.122. PMid:26213009.

Guilherme, A. A., Dantas, P. V. F., Santos, E. S., Fernandes, F. A. N., \& Macedo, G. R. (2015). Evaluation of composition, characterization and enzymatic hydrolysis of pretreated sugar cane bagasse. Brazilian Journal of Chemical Engineering, 32(1), 23-33. http://dx.doi. org/10.1590/0104-6632.20150321s00003146.

Guimarães, B. P., Neves, E. L. P., Guimarães, M. G., \& Ghesti, G. F. (2020). Evaluation of maturation congeners in beer aged with Brazilian woods. Journal of Brewing and Distilling, 9(1), 1-7. https:// doi.org/10.5897/JBD2019.0053.

Hager, A. S., Taylor, J. P., Waters, D. M., \& Arendt, E. K. (2014). Gluten free beer - A review. Trends in Food Science \& Technology, 36(1), 44-54. http://dx.doi.org/10.1016/j.tifs.2014.01.001. 
Holt, S., Miks, M. H., de Carvalho, B. T., Foulquié-Moreno, M. R., \& Thevelein, J. M. (2019). The molecular biology of fruity and floral aromas in beer and other alcoholic beverages. FEMS Microbiology Reviews, 43(3), 193-222. http://dx.doi.org/10.1093/ femsre/fuy041. PMid:30445501.

Kallscheuer, N. (2018). Engineered microorganisms for the production of food additives approved by the European Union-A systematic analysis. Frontiers in Microbiology, 9, 1746. http://dx.doi.org/10.3389/ fmicb.2018.01746. PMid:30123195.

Kreft, I., Fabjan, N., \& Yasumoto, K. (2006). Rutin content in buckwheat (Fagopyrum esculentum Moench) food materials and products. Food Chemistry, 98(3), 508-512. http://dx.doi.org/10.1016/j. foodchem.2005.05.081.

Kunze, W. (2004). Technology brewing and malting (3rd ed.). Berlin: VLB Berlin.

MacLeod, L., \& Evans, E. (2015). Barley: malting. In C. Wrigley, H. Corke, K. Seetharaman \& J. Faubion (Eds.), Encyclopedia of food grains (2nd ed., pp. 423-433). Cambridge: Academic Press. https:// doi.org/10.1016/B978-0-12-394437-5.00153-4.

Mallett, J. (2014). Malt: a practical guide from field to brewhouse. Colorado: Brewers Publications.

Mazza, G., \& Oomah, B. D. (2003). BUCKWHEAT. In B. Caballero (Ed.), Encyclopedia of food sciences and nutrition (pp. 692-699). Cambridge: Academic Press. https://doi.org/10.1016/B0-12-227055-X/00132-2.

Muller, C. V. (2018). O controle oficial de fraudes em cerveja no Brasil - estudo de caso (Dissertação de mestrado). Universidade de Brasília, Brasília.

Muller, C., Neves, L. E., Gomes, L., Guimarães, M., \& Ghesti, G. (2019). Processes for alcohol-free beer production: a review. Food Science and Technology (Campinas), 40(2), 273-281. http://dx.doi. org/10.1590/fst.32318.

Newman, R. K., \& Newman, C. W. (2008). Health benefits of barley foods. In R. K. Rosemary \& C. W. Newman. Barley for food and health: science, technology and products (Chap. 8, pp. 178-203). London: Wiley-Blackwell. http://dx.doi.org/10.1002/9780470369333.ch8

Parachin, N. S., \& Ghesti, G. F. (2017). Microbes in wine and beer industries. In K.V. Gupta, S. Zeilinger, E. X.F. Filho, M. Bazua \& D. Purchase (Eds.), Microbial applications: recent advancements and future developments (Chap. 8, pp. 177-196). Berlin: De Gruyter.

Phiarais, B. P. N., Mauch, A., Schehl, B. D., Zarnkow, M., Gastl, M., Herrmann, M., Zannini, E., \& Arendt, E. K. (2010). Processing of a top fermented beer brewed from $100 \%$ buckwheat malt with sensory and analytical characterisation. Journal of the Institute of Brewing, 116(3), 265-274. http://dx.doi.org/10.1002/j.2050-0416.2010.tb00430.x.
Pires, E., \& Brányik, T. (2015). Biochemistry of beer fermentation. USA: Springer. http://dx.doi.org/10.1007/978-3-319-15189-2

Raab, A. M., Gebhardt, G., Bolotina, N., Weuster-Botz, D., \& Lang, C. (2010). Metabolic engineering of Saccharomyces cerevisiae for the biotechnological production of succinic acid. Metabolic Engineering, 12(6), 518-525. http://dx.doi.org/10.1016/j.ymben.2010.08.005. PMid:20854924.

Shimadzu Corporation. (2017). Shim-pack HPLC column guidebook. Quioto: Shimadzu Corporation.

Starowicz, M., Koutsidis, G., \& Zieliński, H. (2018). Sensory analysis and aroma compounds of buckwheat containing products - a review. Critical Reviews in Food Science and Nutrition, 58(11), 1767-1779. http://dx.doi.org/10.1080/10408398.2017.1284742. PMid:28686470.

Tomotake, H., Shimaoka, I., Kayashita, J., Nakajoh, M., \& Kato, N. (2002). Physicochemical and functional properties of buckwheat protein product. Journal of Agricultural and Food Chemistry, 50(7), 2125-2129. http://dx.doi.org/10.1021/jf011248q. PMid:11902967.

Van Landschoot, A. (2011). Gluten-free barley malt beers. Cerevisia (Gedrukt), 36(3), 93-97. http://dx.doi.org/10.1016/j.cervis.2011.09.001.

White, C. (2010). Yeast: the practical guide to beer fermentation (brewing elements). Canada: Brewers Publications.

Wijngaard, H. H., \& Arendt, E. K. (2006). Optimisation of a mashing program for $100 \%$ malted Buckwheat. Journal of the Institute of Brewing, 112(1), 57-65. http://dx.doi.org/10.1002/j.2050-0416.2006. tb00708.x.

Wijngaard, H. H., Renzetti, S., \& Arendt, E. K. (2007). Microstructure of buckwheat and barley during malting observed by confocal scanning laser microscopy and scanning electron microscopy. Journal of the Institute of Brewing, 113(1), 34-41. http://dx.doi. org/10.1002/j.2050-0416.2007.tb00253.x.

Wijngaard, H. H., Ulmer, H. M., \& Arendt, E. K. (2005). The effect of germination temperature on malt quality of Buckwheat. Journal of the American Society of Brewing Chemists, 63(1), 31-36.

Wishart, D. S., Feunang, Y. D., Marcu, A., Guo, A. C., Liang, K., VázquezFresno, R., Sajed, T., Johnson, D., Li, C., Karu, N., Sayeeda, Z., Lo, E., Assempour, N., Berjanskii, M., Singhal, S., Arndt, D., Liang, Y., Badran, H., Grant, J., Serra-Cayuela, A., Liu, Y., Mandal, R., Neveu, V., Pon, A., Knox, C., Wilson, M., Manach, C., \& Scalbert, A. (2018). HMDB 4.0: the human metabolome database for 2018. Nucleic Acids Research, 46(D1), D608-D617. http://dx.doi.org/10.1093/nar/ gkx1089. PMid:29140435. 